\title{
Effects of different plantation types on soil properties after vegetation restoration in an alpine sandy land on the Tibetan Plateau, China
}

\author{
LI Qingxue ${ }^{1,2}$, JIA Zhiqing ${ }^{1,2^{*}}$, LIU Tao ${ }^{3}$, FENG Lili ${ }^{1}$, HE Lingxianzi ${ }^{1}$ \\ ${ }^{1}$ Institute of Desertification Studies, Chinese Academy of Forestry, Beijing 100091, China; \\ ${ }^{2}$ Qinghai Gonghe Desert Ecosystem Research Station, Qinghai 813005, China; \\ ${ }^{3}$ Research Institute of Forestry, Chinese Academy of Forestry, Beijing 100091, China
}

\begin{abstract}
Large areas of Artemisia ordosica Krasch., Caragana korshinskii Kom., and Caragana intermedia Kuang and H. C. Fu plantations were established on moving sand dunes in the Gonghe Basin (northeastern Tibetan Plateau) for vegetation restoration. Elevating our understanding of the changes in soil characteristics after the establishment of different plantation types can be useful in the context of combating desertification. To assess the effects of these plantation types on the restoration of sandy land, we measured soil physical-chemical properties at four depths $(0-5,5-10,10-20$, and $20-50 \mathrm{~cm})$ in each of the three plantation types and also in non-vegetated moving sand dunes (as control sites). Generally, the establishment of A. ordosica, C. korshinskii and C. intermedia plantations on sand dunes has greatly ameliorated soil quality in the Gonghe Basin. Specifically, relative to the moving sand dunes, shrub plantation has increased the silt and clay contents, total porosity and water holding capacity, soil organic matter, total nitrogen, total phosphorus and total potassium contents. The calculated soil quality index suggested that in the Gonghe Basin, C. intermedia is the best choice for soil amelioration. In all the three plantation types, soil amelioration mainly occurred in the shallow depths.
\end{abstract}

Keywords: alpine sandy land; plantation types; soil property; soil amelioration

Citation: LI Qingxue, JIA Zhiqing, LIU Tao, FENG Lili, HE Lingxianzi. 2017. Effects of different plantation types on soil properties after vegetation restoration in an alpine sandy land on the Tibetan Plateau, China. Journal of Arid Land, 9(2): 200209. doi: 10.1007/s40333-017-0006-6

\section{Introduction}

Revegetation has long been advocated to be an effective way to combat the widespread desertification (Luo et al., 2014). Due to their tolerance to harsh environments, shrub species have been widely favored in the revegetation effort (Wezel et al., 2000; Jiang et al., 2014). The Gonghe Basin of the northeastern Tibetan Plateau, our study area, is a region that has recently been severely affected by desertification, with desert cover-covered area amounting to $91.9 \%$ of the basin (Zhang et al., 2009). Establishing enclosures sand barriers and planting shrubs on shifting sand dunes have been proven to be effective measures for ecologically restoring the land in this region (Lu et al., 2009) and large-scale plantation of shrubs on moving sand dunes with the help of straw checkerboards started as early as 1958 (Zhang et al., 2009).

Some studies have been conducted after the vegetation restoration measures were implemented in the Gonghe Basin. For example, a study revealed that the establishment of artificially sown shrubs can increase the colonization and development of some annual and perennial plant species (Yang et al., 2006). Another study indicated that Caragana intermedia can increase water use 
efficiency to resist drought stress (Jia et al., 2012). And, other studies explored the relationships between the shrub growth stages and soil properties (Liu et al., 2012; Li et al., 2014; Yu and Jia, 2014). However, very few studies have evaluated the effects of plantation types on soil properties in sandy lands. The objective of this study was to investigate the soil physical-chemical properties of three plantation types and compare them with non-vegetated moving sand dunes. The goal was to evaluate the effects of plantation types on soil properties in the sandy lands in the Gonghe Basin (Qinghai Province of China) in hope that our understanding can be useful in the context of combating desertification.

\section{Materials and methods}

\subsection{Study area}

This study was conducted in the Desertification Combating Experimental Site of the Gonghe Desert Ecosystem Research Station $\left(36^{\circ} 14.02^{\prime}-36^{\circ} 14.98^{\prime} \mathrm{N}, 100^{\circ} 14.04^{\prime}-100^{\circ} 14.52^{\prime} \mathrm{E}\right.$; $2871 \mathrm{~m}$ a.s.l.; Fig. 1). The annual mean temperature is $1.0^{\circ} \mathrm{C}-5.2^{\circ} \mathrm{C}$, the winter temperature is $-20.8^{\circ} \mathrm{C}--$ $31.0^{\circ} \mathrm{C}$ and the summer temperature is $27.7^{\circ} \mathrm{C}-42.2^{\circ} \mathrm{C}$. The mean annual precipitation is $311.1-$ $402.1 \mathrm{~mm}$ with nearly $50 \%$ occurring during the growing season (mainly July and August). The mean annual potential evaporation is 1528-1937 $\mathrm{mm}$ (Dong et al., 1993). The mean annual number of windy days is $51 \mathrm{~d}$ (with a maximum of $97 \mathrm{~d}$ ), and the mean annual number of sandstorm days is $21 \mathrm{~d}$. The annual mean wind speed is $2.7 \mathrm{~m} / \mathrm{s}$ and the maximum wind speed reaches $40.0 \mathrm{~m} / \mathrm{s}$ (Jia et al., 2012). The zonal soils are chestnut soil and brown soil, while the azonal soils are aeolian-, meadow- and bog-related. The main vegetation type is sand-fixing plantation species, including tree species (e.g., Populus cathayana and P. simonii), shrub species (e.g., C. intermedia, C. korshinskii, Hippophae rhamnoides, Salix cheilophila and S. psammophila), and semi-shrub species (e.g., Artemisia ordosica). The natural herbaceous species include Suaeda glauca, Leymus secalinus, Artemisia sieversiana, Salsola collina, Agropyron cristatum, Orinus kokonorica and Glycyrrhiza uralensis (Zhang et al., 2009).

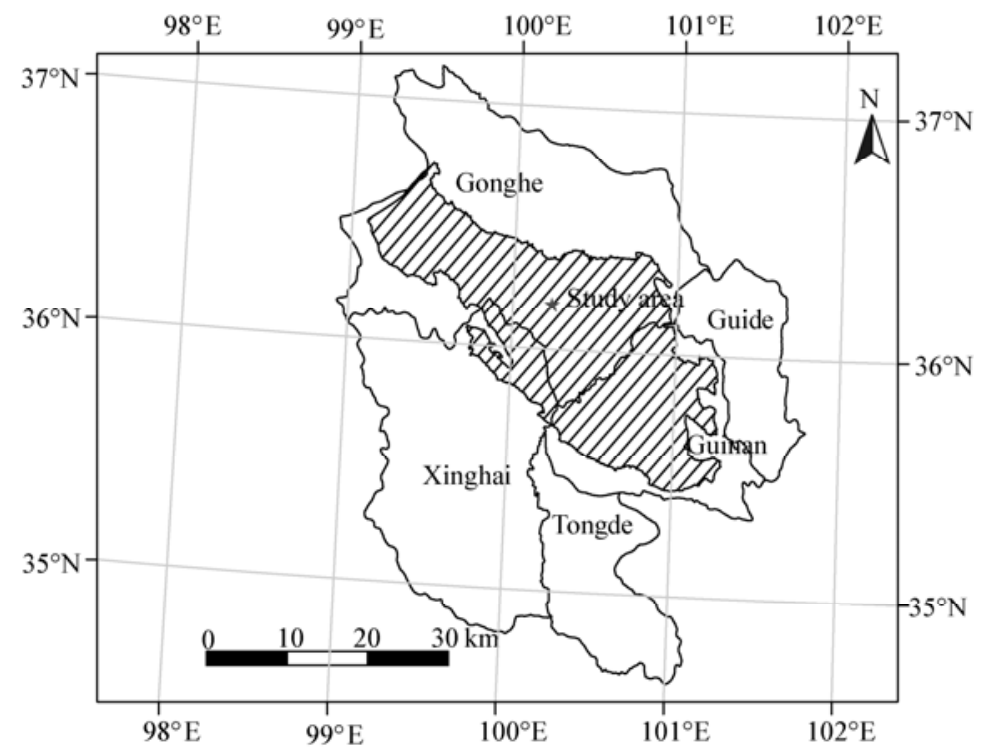

Fig. 1 Location of the study area, Gonghe County, Qinghai Province, China

\subsection{Experimental design and soil sampling}

Artemisia ordosica, Caragana korshinskii, and Caragana intermedia are naturally light-tolerant and drought-resistant species. Specifically, A. ordosica is a semi-shrub species that is widely distributed in the sandy areas of northern and northwestern China (Li et al., 2000). Caragana 
korshinskii and C. intermedia are leguminous shrub species that are commonly found in arid and semi-arid lands in northwestern China (Fang et al., 2006; Li et al., 2014). These three species are widely used in vegetation restoration in the Gonghe Basin to stabilize the shifting sand, therefore, three plantation types of A. ordosica, C. korshinskii, and C. intermedia, covering $20 \mathrm{hm}^{2}$ in total, were selected as the study sites. Artemisia ordosica, C. korshinskii, and C. intermedia seedlings were planted on moving sand dunes in 1986 using straw checkerboards (consisting of $1 \mathrm{~m} \times 1 \mathrm{~m}$ squares) as sand binders. The planting was arranged in belts and the orientation of the belts was perpendicular to the prevailing wind direction. All plantation types were enclosed after planting. It should be noted that these three plantation types were established in the same year under similar physiographic settings, and it can thus be assumed that the soils were similar prior to plantations. Additionally, we selected four non-vegetated moving sand dunes sites as the control sites for comparison purpose.

The soil samples were collected in July 2013. In each plantation type, four representative plots (four replications, $10 \mathrm{~m} \times 10 \mathrm{~m}$ ) with similar topographical traits were selected for sampling. The four plots were more than $50 \mathrm{~m}$ away from each other. In each plot, the morphological characteristics of 10 plants were measured, including height (height of the highest shoot), crown diameter (mean of maximum diameter of the shrub canopy) and ground diameter (mean of maximum diameter of the shrub trunk). The mean morphological characteristics are shown in Table 1.

Table 1 Morphological traits of three plantation types

\begin{tabular}{lcccc}
\hline Plantation type & Height $(\mathrm{cm})$ & Crown diameter $(\mathrm{cm})$ & Ground diameter $(\mathrm{cm})$ & Array spacing $(\mathrm{m})$ \\
\hline Moving sand dunes (control) & NA & NA & NA & NA \\
Artemisia ordosica & $35.75 \pm 4.87^{\mathrm{a}}$ & $40.25 \pm 4.96^{\mathrm{a}}$ & $12.88 \pm 1.63^{\mathrm{a}}$ & $1 \times 1$ \\
Caragana korshinskii & $249.50 \pm 31.28^{\mathrm{c}}$ & $153.00 \pm 20.19^{\mathrm{b}}$ & $41.88 \pm 2.16^{\mathrm{b}}$ & $1 \times 2$ \\
Caragana intermedia & $137.50 \pm 5.04^{\mathrm{b}}$ & $137.38 \pm 2.74^{\mathrm{b}}$ & $78.00 \pm 9.86^{\mathrm{c}}$ & $1 \times 2$ \\
\hline
\end{tabular}

Note: Values are means \pm standard error. Values followed by different lowercase letters indicate a significant difference among shrubs, according to Duncan's multiple range test $(P<0.05)$. NA, not applicable.

In each plot, soil samples were collected at 10 sites (more or less randomly selected) at the depths of $0-5,5-10,10-20$, and $20-50 \mathrm{~cm}$. All of the soil samples collected from the same depth at each plot were mixed to form a composite soil sample representing the soil of that depth for the entire plot. Consequently, we had a composite soil sample for each one of the sampled depths (i.e., 0-5, 5-10, 10-20, and 20-50 cm). At each moving sand dune site, soil samples were collected randomly at depths of $0-5,5-10,10-20$ and 20-50 cm. Soil samples were collected by zip-lock bag and taken back to laboratory, air-dried and stored at room temperature for later soil physical and chemical analyses.

\subsection{Laboratory analysis}

The soil bulk density (BD), maximum water holding capacity (MWHC), capillary water holding capacity (CWHC) and total porosity (Total Po) were measured using the cutting ring method (stainless steel cylinders with a volume of $100 \mathrm{~cm}^{3}$ ). The collected soils along with the cutting rings of each depth for every sampling point were weighed $\left(m_{1}\right)$ after soaking for $12 \mathrm{~h}$ in water to estimate the MWHC. Then, the cutting rings were placed on dry sand for $2 \mathrm{~h}$, allowing the non-pore water to be completely drained, then weighed $\left(m_{2}\right)$ for calculating the CWHC. Finally, cutting rings were dried at $105^{\circ} \mathrm{C}$ for $48 \mathrm{~h}$ to a constant weight $\left(m_{3}\right)$, and then the soils were removed and the cutting rings were weighed $\left(m_{0}\right)$. The equations of $\mathrm{BD}, \mathrm{MWHC}, \mathrm{CWHC}$, and Total Po were as follows (Zhang and $\mathrm{Xu}, 1986$; Gao et al., 2015):

$$
\begin{aligned}
& B D=\left(m_{3}-m_{0}\right) / 100, \\
& M W H C=\left(m_{1}-m_{3}\right) /\left(m_{3}-m_{0}\right) \times 100, \\
& C W H C=\left(m_{2}-m_{3}\right) /\left(m_{3}-m_{0}\right) \times 100, \\
& \text { Total } P o=M W H C \times B D .
\end{aligned}
$$

Air-dried soil was passed through a $2-\mathrm{mm}$ mesh. One part of the soil sample was used for soil 
texture analysis and the other was ground and passed through a $0.25-\mathrm{mm}$ mesh for soil nutrient analysis. A soil texture analysis was undertaken using the pipette method, and soil organic matter (SOM) was measured using the $\mathrm{K}_{2} \mathrm{Cr}_{2} \mathrm{O}_{7}-\mathrm{H}_{2} \mathrm{SO}_{4}$ oxidation method. Total nitrogen (TN) was measured by the Kjeldahl method, total phosphorus (TP) was measured using the Mo-Sb colorimetric method and total potassium (TK) was measured by the atomic absorption method. All analyses were based on the Physical and Chemical Analysis Methods for Soils (Institute of Soil Sciences, Chinese Academy of Sciences (ISSCAS), 1978).

\subsection{Soil quality index}

The method first described by Bastida et al. (2006) and late improved by Masto et al. (2008) and Zhang et al. (2011) was followed to elaborate the soil quality index (SQI). The elaboration consisted of the following steps: (1) selecting of appropriate parameters, (2) transforming and weighing values, and (3) combining the scores into an index (Bastida et al., 2006; Sinha et al., 2009; Zhang et al., 2011). Specifically, a principal component analysis (PCA) was used to select the appropriate parameters and their weighing factors. In each principal component (PC), only the variables with high factor loadings were retained for indexing (Andrews et al., 2002). If there was more than one variable with a high loading in a single PC, only the parameters that were uncorrelated with each other (determined by the Pearson's correlation analysis) were considered to be important and were therefore selected. If the high-loading variables were well correlated, the variable with the highest factor loading was finally chosen for calculating SQI (Sinha et al., 2009; Zhang et al., 2011).

To transform the real values of soil properties into scores $(Y)$, we used a sigmoidal-type equation (Bastida et al., 2006; Masto et al., 2008; Zhang et al., 2011) with an asymptote tending to 1 and another tending to 0 .

$$
Y=a /\left(1+\left(x / x_{0}\right)^{b}\right) \text {. }
$$

Where, $Y$ is the respective score; $a$, the maximum score (in the present case, $a=1$ ); $x$, the soil property value; $x_{0}$, the mean value of each property corresponding to the soil; $b$, the value of the slope of the equation. The slope was -2.5 for the "more is better" and 2.5 for the "less is better" to obtain a sigmoidal curve tending to 1 for all the proposed properties.

The final PCA-based SQI equation is as follows:

$$
S Q I=\sum_{i=1}^{n} W_{i} Y_{i}
$$

Where, $W$ is the weighing factor of the soil properties selected by PCA. Each PC explained a certain amount of variation in the total dataset. This percentage provided the weight for variables chosen under a given PC (Masto et al., 2008; Sinha et al., 2009; Zhang et al., 2011).

\subsection{Statistical analysis}

All results are reported as the means \pm standard error (SE). A one-way ANOVA was used to analyze the difference between mean values, and Duncan's multiple range tests were selected to compare the means, calculated at $P<0.05$ level. SPSS 18.0 software was used for statistical analyses.

\section{Results}

\subsection{Soil physical properties}

The variations in soil texture are shown in Table 2. The mean sand contents in the three plantations were all significantly lower than those in the moving sand dunes. Among the three plantations, C. intermedia plantation had the lowest sand content, followed by the C. korshinskii plantation. In contrast, the mean silt contents in the three plantations were all significantly higher than those in the moving sand dunes. Again, among the three plantations, the C. intermedia plantation had the highest silt content, also followed by the $C$. korshinskii plantation. The mean clay contents in the three plantations are all significantly higher than those in the moving sand dunes. Like the silt content, the highest clay content was detected in the $C$. intermedia plantation. But unlike silt content, the second highest clay content was detected in the A. ordosica plantation (not in the C. korshinskii plantation). 
Table 2 Variations in soil physical properties at four soil depths in the moving sand dunes and three plantations

\begin{tabular}{|c|c|c|c|c|c|}
\hline Index & $\begin{array}{l}\text { Depth } \\
(\mathrm{cm})\end{array}$ & Moving sand dunes & A. ordosica & C. korshinskii & C. intermedia \\
\hline \multirow{4}{*}{$\begin{array}{l}\text { Sand } \\
(2-0.02 \mathrm{~mm}, \%)\end{array}$} & $0-5$ & $92.493 \pm 0.390^{\mathrm{Ac}}$ & $89.978 \pm 0.712^{\mathrm{Ab}}$ & $89.773 \pm 0.218^{\mathrm{Ab}}$ & $87.525 \pm 0.584^{\mathrm{Aa}}$ \\
\hline & $5-10$ & $93.528 \pm 0.223^{\mathrm{Ad}}$ & $91.863 \pm 0.390^{\mathrm{Bc}}$ & $90.813 \pm 0.147^{\mathrm{Bb}}$ & $89.088 \pm 0.258^{\mathrm{Ba}}$ \\
\hline & $10-20$ & $93.903 \pm 0.277^{\mathrm{Ac}}$ & $91.995 \pm 0.648^{\mathrm{Bb}}$ & $91.618 \pm 0.152^{\mathrm{Bab}}$ & $90.495 \pm 0.263^{\mathrm{Ca}}$ \\
\hline & $20-50$ & $93.650 \pm 0.650^{\mathrm{Aa}}$ & $93.450 \pm 0.435^{\mathrm{Ba}}$ & $92.600 \pm 0.548^{\mathrm{Ca}}$ & $92.250 \pm 0.395^{\mathrm{Da}}$ \\
\hline More than MSD (\%) & & & -1.68 & -2.35 & -3.81 \\
\hline \multirow{4}{*}{$\begin{array}{l}\text { Silt } \\
(0.02-0.002 \mathrm{~mm}, \%)\end{array}$} & $0-5$ & $5.285 \pm 0.280^{\mathrm{Aa}}$ & $6.190 \pm 0.320^{\mathrm{Bab}}$ & $7.070 \pm 0.259^{\mathrm{Bb}}$ & $8.083 \pm 0.350^{\mathrm{Cc}}$ \\
\hline & $5-10$ & $5.125 \pm 0.147^{\mathrm{Aa}}$ & $5.493 \pm 0.269^{\mathrm{Ba}}$ & $6.668 \pm 0.050^{\mathrm{Bb}}$ & $7.273 \pm 0.143^{\mathrm{BCc}}$ \\
\hline & $10-20$ & $4.670 \pm 0.200^{\mathrm{Aa}}$ & $5.943 \pm 0.322^{\mathrm{Bb}}$ & $6.310 \pm 0.165^{\mathrm{Bbc}}$ & $6.908 \pm 0.178^{\mathrm{Bc}}$ \\
\hline & $20-50$ & $4.500 \pm 0.580^{\mathrm{Aa}}$ & $4.250 \pm 0.299^{\mathrm{Aa}}$ & $5.000 \pm 0.852^{\mathrm{Aa}}$ & $5.450 \pm 0.519^{\mathrm{Aa}}$ \\
\hline More than MSD (\%) & & & 11.64 & 27.87 & 41.45 \\
\hline \multirow{4}{*}{$\begin{array}{l}\text { Clay } \\
(<0.002 \mathrm{~mm}, \%)\end{array}$} & $0-5$ & $2.218 \pm 0.229^{\mathrm{Ba}}$ & $3.835 \pm 0.526^{\mathrm{Bbc}}$ & $3.158 \pm 0.081^{\mathrm{Bab}}$ & $4.393 \pm 0.261^{\mathrm{Cc}}$ \\
\hline & $5-10$ & $1.348 \pm 0.105^{\mathrm{Aa}}$ & $2.898 \pm 0.414^{\mathrm{Abc}}$ & $2.520 \pm 0.131^{\mathrm{Ab}}$ & $3.640 \pm 0.198^{\mathrm{Bc}}$ \\
\hline & $10-20$ & $1.428 \pm 0.166^{\mathrm{Aa}}$ & $2.063 \pm 0.293^{\mathrm{Ab}}$ & $2.073 \pm 0.046^{\mathrm{Ab}}$ & $2.600 \pm 0.110^{\mathrm{Ab}}$ \\
\hline & $20-50$ & $1.650 \pm 0.171^{\mathrm{Aa}}$ & $2.300 \pm 0.173^{\mathrm{Aa}}$ & $2.150 \pm 0.263^{\mathrm{Aa}}$ & $2.300 \pm 0.191^{\mathrm{Aa}}$ \\
\hline More than MSD (\%) & & & 62.04 & 44.53 & 88.91 \\
\hline \multirow[t]{4}{*}{ Bulk density $\left(\mathrm{g} / \mathrm{cm}^{3}\right)$} & $0-5$ & $1.513 \pm 0.048^{\mathrm{Ab}}$ & $1.478 \pm 0.033^{\mathrm{Aab}}$ & $1.415 \pm 0.022^{\mathrm{Aab}}$ & $1.378 \pm 0.005^{\mathrm{Aa}}$ \\
\hline & $5-10$ & $1.520 \pm 0.023^{\mathrm{Ab}}$ & $1.503 \pm 0.014^{\mathrm{Ab}}$ & $1.480 \pm 0.015^{\mathrm{ABab}}$ & $1.430 \pm 0.017^{\mathrm{ABa}}$ \\
\hline & $10-20$ & $1.543 \pm 0.042^{\mathrm{Aa}}$ & $1.480 \pm 0.031^{\mathrm{Aa}}$ & $1.515 \pm 0.023^{\mathrm{Ba}}$ & $1.468 \pm 0.026^{\mathrm{Ba}}$ \\
\hline & $20-50$ & $1.550 \pm 0.011^{\mathrm{Aa}}$ & $1.513 \pm 0.013^{\mathrm{Aa}}$ & $1.510 \pm 0.024^{\mathrm{Ba}}$ & $1.468 \pm 0.022^{\mathrm{Ba}}$ \\
\hline More than MSD (\%) & & & -2.77 & -3.43 & -6.20 \\
\hline \multirow[t]{4}{*}{ Total porosity (\%) } & $0-5$ & $40.750 \pm 1.220^{\mathrm{Ba}}$ & $45.200 \pm 1.747^{\mathrm{Bb}}$ & $49.825 \pm 0.995^{\mathrm{Cc}}$ & $47.775 \pm 0.772^{\mathrm{Bbc}}$ \\
\hline & $5-10$ & $41.075 \pm 0.884^{\mathrm{Ba}}$ & $45.000 \pm 0.994^{\mathrm{Bb}}$ & $46.200 \pm 1.128^{\mathrm{Bb}}$ & $43.025 \pm 1.490^{\text {Aab }}$ \\
\hline & $10-20$ & $42.025 \pm 0.673^{\mathrm{Ba}}$ & $40.125 \pm 1.396^{\mathrm{Aa}}$ & $42.225 \pm 0.889^{\mathrm{Aa}}$ & $41.925 \pm 0.872^{\mathrm{Aa}}$ \\
\hline & $20-50$ & $35.775 \pm 0.545^{\mathrm{Aa}}$ & $37.325 \pm 0.450^{\mathrm{Aab}}$ & $39.975 \pm 1.285^{\mathrm{Ab}}$ & $40.350 \pm 1.555^{\mathrm{Ab}}$ \\
\hline More than MSD (\%) & & & 5.02 & 11.65 & 8.43 \\
\hline \multirow{4}{*}{$\begin{array}{l}\text { Maximum water } \\
\text { holding capacity (\%) }\end{array}$} & $0-5$ & $27.075 \pm 1.539^{\mathrm{Ba}}$ & $30.743 \pm 1.807^{\mathrm{Bab}}$ & $35.210 \pm 0.966^{\mathrm{Cbc}}$ & $34.670 \pm 0.605^{\mathrm{Cc}}$ \\
\hline & $5-10$ & $29.628 \pm 1.118^{\mathrm{Ba}}$ & $27.303 \pm 0.676^{\mathrm{ABa}}$ & $31.255 \pm 1.076^{\mathrm{Ba}}$ & $30.190 \pm 1.056^{\mathrm{Ba}}$ \\
\hline & $10-20$ & $27.275 \pm 0.823^{\mathrm{Ba}}$ & $27.195 \pm 1.319^{\mathrm{ABa}}$ & $27.930 \pm 0.954^{\mathrm{Aa}}$ & $28.620 \pm 0.742^{\mathrm{ABa}}$ \\
\hline & $20-50$ & $23.055 \pm 0.300^{\mathrm{Aa}}$ & $24.705 \pm 0.164^{\mathrm{Aab}}$ & $26.533 \pm 1.195^{\mathrm{Abc}}$ & $27.480 \pm 0.826^{\mathrm{Ac}}$ \\
\hline More than MSD (\%) & & & 2.72 & 12.99 & 13.02 \\
\hline \multirow{4}{*}{$\begin{array}{l}\text { Capillary water } \\
\text { holding capacity }(\%)\end{array}$} & $0-5$ & $20.880 \pm 1.218^{\mathrm{ABa}}$ & $25.563 \pm 1.128^{\mathrm{Bb}}$ & $28.859 \pm 1.139^{\mathrm{Bb}}$ & $28.298 \pm 1.334^{\mathrm{Bb}}$ \\
\hline & $5-10$ & $23.738 \pm 1.570^{\mathrm{Ba}}$ & $22.520 \pm 0.781^{\mathrm{ABa}}$ & $25.980 \pm 1.142^{\mathrm{ABa}}$ & $25.660 \pm 0.931^{\mathrm{ABa}}$ \\
\hline & $10-20$ & $22.485 \pm 0.561^{\mathrm{Ba}}$ & $22.678 \pm 1.611^{\mathrm{ABa}}$ & $23.355 \pm 2.159^{\mathrm{Aa}}$ & $24.033 \pm 0.541^{\mathrm{Aa}}$ \\
\hline & $20-50$ & $18.185 \pm 0.257^{\mathrm{Aa}}$ & $19.758 \pm 0.830^{\mathrm{Aa}}$ & $22.415 \pm 0.683^{\mathrm{Ab}}$ & $23.353 \pm 0.922^{\mathrm{Ab}}$ \\
\hline More than MSD (\%) & & & 6.12 & 17.95 & 18.80 \\
\hline
\end{tabular}

Note: MSD, moving sand dunes. Values in row followed by different lowercase letters indicate a significant difference between the moving sand dunes and three plantations, and values followed by different uppercase letters indicate a significant difference between the soil depths, according to Duncan's multiple range test $(P<0.05)$. Values are means \pm SE, $n=4$.

Compared with the moving sand dunes, the three plantations all have reduced the bulk density (BD), especially at the shallow depths (e.g., 0-10 cm). Again, the C. intermedia plantation is the leading one in reducing $\mathrm{BD}$, also followed by the $C$. korshinskii plantation. In terms of porosity reduction, the $C$. korshinskii plantation takes the lead (reduced by $11.65 \%$ compared with the moving sand dunes), followed by the C. intermedia plantation (reduced by $8.43 \%$ ). The three plantations, especially the latter two (i.e., C. korshinskii and C. intermedia), can rather effectively 
enhance both the maximum water holding capacity (MWHC) and the capillary water holding capacity (CWHC). Table 2 shows that C. korshinskii and C. intermedia plantations increased MWHC by $13 \%$ and increased CWHC by $18 \%$.

\subsection{Soil chemical properties}

Table 3 shows the effects of the three plantations on soil organic matter (SOM), total nitrogen (TN), total phosphorus (TP), and total potassium (TK). All the three plantations, especially $C$. korshinskii and C. intermedia, have rather effectively increased SOM, TN, TP and TK contents particularly at the shallow depths (e.g., $0-10 \mathrm{~cm}$ ). Compared with the moving sand dunes, the mean SOM contents of A. ordosica, C. korshinskii and C. intermedia plantations increased by $48.46 \%, 113.13 \%$ and $187.85 \%$, respectively; the mean TN contents increased by $92.86 \%, 485.71 \%$ and $585.71 \%$, respectively; the mean TP contents increased by $29.63 \%, 70.37 \%$ and $118.52 \%$, respectively; and the mean TK contents increased by $3.08 \%, 7.50 \%$ and $13.63 \%$, respectively.

Table 3 Changes in soil chemical properties at four soil depths in the moving sand dunes and three plantations

\begin{tabular}{|c|c|c|c|c|c|}
\hline Index & $\begin{array}{l}\text { Depth } \\
\text { (cm) }\end{array}$ & $\begin{array}{l}\text { Moving sand } \\
\text { dunes }\end{array}$ & A. ordosica & C. korshinskii & C. intermedia \\
\hline \multirow{4}{*}{$\begin{array}{l}\text { Soil organic matter } \\
\quad(g / \mathrm{kg})\end{array}$} & $0-5$ & $1.840 \pm 0.082^{\mathrm{Aa}}$ & $3.803 \pm 0.734^{\mathrm{Bb}}$ & $5.890 \pm 0.602^{\mathrm{Bc}}$ & $7.515 \pm 0.382^{\mathrm{Dd}}$ \\
\hline & $5-10$ & $1.793 \pm 0.125^{\mathrm{Aa}}$ & $2.815 \pm 0.290^{\mathrm{ABab}}$ & $3.573 \pm 0.297^{\mathrm{Ab}}$ & $5.638 \pm 0.504^{\mathrm{Cc}}$ \\
\hline & $10-20$ & $1.763 \pm 0.131^{\mathrm{Aa}}$ & $2.195 \pm 0.246^{\mathrm{Aa}}$ & $3.145 \pm 0.211^{\mathrm{Ab}}$ & $4.363 \pm 0.410^{\mathrm{Bc}}$ \\
\hline & $20-50$ & $1.765 \pm 0.053^{\mathrm{Aa}}$ & $1.820 \pm 0.077^{\mathrm{Aa}}$ & $2.650 \pm 0.147^{\mathrm{Ab}}$ & $3.083 \pm 0.297^{\mathrm{Ab}}$ \\
\hline More than MSD (\%) & & & 48.46 & 113.13 & 187.85 \\
\hline \multirow[t]{4}{*}{ Total nitrogen $(\mathrm{g} / \mathrm{kg})$} & $0-5$ & $0.055 \pm 0.003^{\mathrm{Ba}}$ & $0.093 \pm 0.005^{\mathrm{Ca}}$ & $0.328 \pm 0.010^{\mathrm{Db}}$ & $0.343 \pm 0.036^{\mathrm{Cb}}$ \\
\hline & $5-10$ & $0.038 \pm 0.009^{\mathrm{Aa}}$ & $0.073 \pm 0.009^{\mathrm{Bb}}$ & $0.218 \pm 0.005^{\mathrm{Cc}}$ & $0.253 \pm 0.015^{\mathrm{Bd}}$ \\
\hline & $10-20$ & $0.025 \pm 0.003^{\mathrm{Aa}}$ & $0.055 \pm 0.003^{\mathrm{ABa}}$ & $0.158 \pm 0.005^{\mathrm{Bb}}$ & $0.215 \pm 0.025^{\mathrm{ABc}}$ \\
\hline & $20-50$ & $0.025 \pm 0.003^{\mathrm{Aa}}$ & $0.045 \pm 0.003^{\mathrm{Ab}}$ & $0.123 \pm 0.008^{\mathrm{Ac}}$ & $0.148 \pm 0.005^{\mathrm{Ad}}$ \\
\hline More than MSD (\%) & & & 92.86 & 485.71 & 585.71 \\
\hline \multirow{4}{*}{$\begin{array}{l}\text { Total phosphorus } \\
\qquad(\mathrm{g} / \mathrm{kg})\end{array}$} & $0-5$ & $0.138 \pm 0.011^{\mathrm{Aa}}$ & $0.188 \pm 0.010^{\text {Bab }}$ & $0.263 \pm 0.027^{\mathrm{Bb}}$ & $0.360 \pm 0.043^{\mathrm{Bc}}$ \\
\hline & $5-10$ & $0.135 \pm 0.009^{\mathrm{Aa}}$ & $0.185 \pm 0.003^{\mathrm{Bb}}$ & $0.258 \pm 0.022^{\mathrm{Bc}}$ & $0.333 \pm 0.022^{\mathrm{Bd}}$ \\
\hline & $10-20$ & $0.140 \pm 0.009^{\mathrm{Aa}}$ & $0.158 \pm 0.006^{\mathrm{Aa}}$ & $0.213 \pm 0.003^{\mathrm{ABb}}$ & $0.280 \pm 0.021^{\mathrm{ABc}}$ \\
\hline & $20-50$ & $0.120 \pm 0.015^{\mathrm{Aa}}$ & $0.168 \pm 0.009^{\mathrm{ABb}}$ & $0.190 \pm 0.004^{\mathrm{Ab}}$ & $0.208 \pm 0.018^{\mathrm{Ab}}$ \\
\hline More than MSD (\%) & & & 29.63 & 70.37 & 118.52 \\
\hline \multirow[t]{4}{*}{ Total potassium $(\mathrm{g} / \mathrm{kg})$} & $0-5$ & $12.270 \pm 0.204^{\mathrm{Aa}}$ & $12.695 \pm 0.169^{\mathrm{Aa}}$ & $13.733 \pm 0.196^{\mathrm{Ab}}$ & $14.970 \pm 0.503^{\mathrm{Bc}}$ \\
\hline & $5-10$ & $12.088 \pm 0.134^{\mathrm{Aa}}$ & $12.585 \pm 0.108^{\mathrm{Aab}}$ & $13.093 \pm 0.370^{\mathrm{Ab}}$ & $14.033 \pm 0.292^{\mathrm{ABc}}$ \\
\hline & $10-20$ & $12.440 \pm 0.235^{\mathrm{Aa}}$ & $12.475 \pm 0.185^{\mathrm{Aa}}$ & $12.838 \pm 0.222^{\mathrm{Aa}}$ & $13.393 \pm 0.544^{\mathrm{Aa}}$ \\
\hline & $20-50$ & $11.853 \pm 0.493^{\mathrm{Aa}}$ & $12.385 \pm 0.360^{\mathrm{Aa}}$ & $12.633 \pm 0.361^{\mathrm{Aa}}$ & $12.883 \pm 0.467^{\mathrm{Aa}}$ \\
\hline More than MSD (\%) & & & 3.08 & 7.50 & 13.63 \\
\hline
\end{tabular}

Note: MSD, moving sand dunes. Values in row followed by different lowercase letters indicate a significant difference between the moving sand dunes and three plantations, and values followed by different uppercase letters indicate a significant difference between the soil depths, according to Duncan's multiple range test $(P<0.05)$. Values are means $\pm \mathrm{SE}, n=4$.

\subsection{Soil quality index (SQI)}

All soil parameters for calculating the SQI were chosen through the PCA. As shown in Table 4, the eigenvalues of the first two PCs (principal components) were above 1, and the highly weighted parameters in PC-1 were sand, silt, MWHC, SOM, TN and TP. Silt had the highest loading and was highly correlated with sand, MWHC, SOM, TN and TP ( $r>0.85$, Table 5); thus, sand, MWHC, SOM, TN and TP were eliminated from the SQI. In PC-2, the highly loaded parameters included total porosity and MWHC, both of them correlate significantly $(r=0.90)$, and total porosity had the highest loading; therefore, MWHC was eliminated from the SQI. In summary, the most important parameters as determined through the PCA for the SQI calculation were silt and total porosity (Table 4). The final polynomial for the SQI was calculated using 
Equation 6 (Table 6). The SQI differed among the different plantation types; C. intermedia (0.508) had the highest value, followed by C. korshinskii (0.462) and then A. ordosica (0.394). The SQI of all plantation types was higher than that of moving sand dunes (0.340).

Table 4 Principal component analysis of soil properties of moving sand dunes and different plantation types

\begin{tabular}{lcc}
\hline & Principal component 1 & Principal component 2 \\
\hline Eigenvalue & 8.404 & 1.053 \\
Variance (\%) & 76.397 & 9.574 \\
Cumulative variance (\%) & 76.397 & 85.971 \\
Eigenvectors & & 0.162 \\
Sand (2-0.02 mm) & -0.952 & 0.018 \\
Silt (0.02-0.002 mm) & 0.973 & -0.321 \\
Clay (<0.002 mm) & 0.769 & -0.169 \\
Bulk density (BD) & -0.812 & 0.498 \\
Total porosity (Total Po) & 0.793 & 0.450 \\
Maximum water holding capacity (MWHC) & 0.879 & 0.397 \\
Capillary water holding capacity (CWHC) & 0.872 & -0.388 \\
Soil organic matter (SOM) & 0.886 & -0.108 \\
Total nitrogen (TN) & 0.934 & -0.317 \\
Total phosphorus (TP) & 0.886 & -0.155 \\
Total potassium (TK) & 0.833 & \\
\hline
\end{tabular}

Table 5 Correlation matrix among different soil properties determined

\begin{tabular}{lcccccccccc}
\hline & Sand & Silt & Clay & BD & Total Po & MWHC & CWHC & SOM & TN & TP \\
\hline Silt & $-0.958^{* *}$ & & & & & & & & & \\
Clay & $-0.890^{* *}$ & $0.736^{* *}$ & & & & & & & & \\
BD & $0.791^{* *}$ & $-0.816^{* *}$ & $-0.690^{* *}$ & & & & & & & \\
Total Po & $-0.667^{* *}$ & $0.714^{* *}$ & 0.479 & $-0.602^{*}$ & & & & & & \\
MWHC & $-0.747^{* *}$ & $0.847^{* *}$ & 0.493 & $-0.817^{* *}$ & $0.904^{* *}$ & & & & & \\
CWHC & $-0.767^{* *}$ & $0.856^{* *}$ & $0.532^{*}$ & $-0.712^{* *}$ & $0.872^{* *}$ & $0.915^{* *}$ & & & & \\
SOM & $-0.871^{* *}$ & $0.864^{* *}$ & $0.711^{* *}$ & $-0.560^{*}$ & $0.544^{*}$ & $0.611^{*}$ & $0.622^{*}$ & & & \\
TN & $-0.855^{* *}$ & $0.891^{* *}$ & $0.632^{* *}$ & $-0.619^{*}$ & $0.728^{* *}$ & $0.793^{* *}$ & $0.766^{* *}$ & $0.930^{* *}$ & & \\
TP & $-0.842^{* *}$ & $0.846^{* *}$ & $0.681^{* *}$ & $-0.646^{* *}$ & $0.544^{*}$ & $0.655^{* *}$ & $0.644^{* *}$ & $0.926^{* *}$ & $0.921^{* *}$ & \\
TK & $-0.743^{* *}$ & $0.792^{* *}$ & $0.564^{*}$ & $-0.566^{*}$ & $0.585^{*}$ & $0.661^{* *}$ & $0.687^{* *}$ & $0.830^{* *}$ & $0.794^{* *}$ & $0.762^{* *}$ \\
\hline
\end{tabular}

Notes: BD, bulk density; Total Po, total porosity; MWHC, maximum water holding capacity; CWHC, capillary water holding capacity; SOM, soil organic matter; TN, total nitrogen; TP, total phosphorus; TK, total potassium. ${ }^{*}$, correlation significant at the 0.05 level (2-tailed); ${ }^{* *}$, correlation significant at the 0.01 level (2-tailed).

Table 6 Soil quality index of moving sand dunes and different plantation types

\begin{tabular}{|c|c|c|c|c|c|c|c|}
\hline Index & Parameter & Moving sand dunes & A. ordosica & C. korshinskii & C. intermedia & $x_{0}$ & $b$ \\
\hline \multirow{3}{*}{ Silt } & $x$ & 4.898 & 5.468 & 6.263 & 6.928 & 5.889 & -2.500 \\
\hline & $Y$ & 0.387 & 0.454 & 0.538 & 0.600 & I & l \\
\hline & $W$ & 0.764 & 0.764 & 0.764 & 0.764 & I & / \\
\hline \multirow{3}{*}{ Total porosity } & $x$ & 39.908 & 41.913 & 44.558 & 43.270 & 42.412 & -2.500 \\
\hline & $Y$ & 0.462 & 0.493 & 0.531 & 0.513 & / & / \\
\hline & $W$ & 0.096 & 0.096 & 0.096 & 0.096 & I & l \\
\hline \multicolumn{2}{|c|}{ Soil quality index (SQI) } & 0.340 & 0.394 & 0.462 & 0.508 & l & / \\
\hline
\end{tabular}




\section{Discussion}

The main purpose of this study was to assess the effects of different plantation types on soil properties after vegetation restoration in an alpine sandy land on the Tibetan Plateau. Our study showed that all of the three plantation types have greatly ameliorated the soil quality. Relative to the moving sand dunes, the soil in all plantation types had more silt, clay and higher organic matter and nutrient contents, higher total porosity and water holding capacity, and lower sand content and bulk density (Tables 2 and 3). The effects of soil improvement can first be attributed to the protective role of plantations against wind erosion (Gao et al., 2014). That is, shrubs can significantly reduce wind velocity and intercept wind-blown fine material (Zuo et al., 2009), leading to increases in silt and clay contents (Yang et al., 2011). The increased fine material not only enhances the formation of soil crust (Li et al., 2002, 2014; Yu and Jia, 2014) but also improves the soil water holding capacity, resulting in increases in organic matter and nutrients $(\mathrm{Su}$ et al., 2005). In addition, the establishment of plantations induces litter accumulation and also root mass decomposition, thus increasing soil organic carbon content (Luo et al., 2014) and also increasing soil nutrients ( $\mathrm{Li}$ et al., 2012; Zhang et al., 2013).

It is sufficiently demonstrated that soil properties can be significantly improved after the establishment of plantations on moving sand dunes. However, the degree of amelioration varies depending on the kind of shrub species used ( $\mathrm{Su}$ et al., 2005). Our study showed that the soil properties significantly differed among the three plantation types. The soil quality index (SQI) showed that $C$. intermedia (0.508) had the highest value, then followed by C. korshinskii ( 0.462$)$, and finally A. ordosica (0.394) (Table 6). There are several possible reasons to explain this phenomenon. First, different plantation types with different morphological traits have different wind-resisting and sand-fixing functions (Bochet et al., 1999). In this study, the height, crown diameter and ground diameter of $C$. intermedia and $C$. korshinskii are significantly larger than $A$. ordosica (Table 1), and they could intercept and accumulate more fine materials and litters than $A$. ordosica, thus resulting in higher SQI values. The SQI of $C$. intermedia is higher than that of $C$. korshinskii, probably because the ground diameter of $C$. intermedia is significantly larger than that of $C$. korshinskii and larger ground diameters may be related to a larger root system, thus more effectively ameliorating soil. It is also quite notable that the total $\mathrm{N}$ content of $C$. intermedia and C. korshinskii are dramatically increased compared with moving sand dunes (increased $585.71 \%$ and $485.71 \%$, respectively). This is because both C. intermedia and C. korshinskii are nitrogen-fixing leguminous shrubs that can fix free nitrogen from the air (Gao et al., 2002; Wang et al., 2006; Jia et al., 2010).

A final note we want to make is the variations of soil properties with depths under the three plantation types. Generally, the plantation-associated of soil quality mainly occurred in shallow depth probably due to the fact the shallow depths were more affected by litter and windblown fine materials (Yang et al., 2011). After establishing shrubs on the sand dunes, the shrubs reduced soil erosion by wind and trapped wind-blown fine materials and dust that were rich in nutrients and were subsequently added to the surface soils through stemflow and throughfall (Cao et al., 2011). Similar results were also reported elsewhere. For instance, in the Horqin Sandy Land, the soil fine fraction, water holding capacity, total nitrogen and organic $\mathrm{C}$ contents increased more significantly in the $0-5 \mathrm{~cm}$ soil layer than in the 5-20 cm soil layer after shrubs were planted on active sand dunes (Su et al., 2005). Dong et al. (2009) reported that soil total organic carbon, total nitrogen, total phosphate, available phosphorus and available potassium contents were significantly higher in the surface layer $(0-5 \mathrm{~cm})$ than in the deeper soil layers in C. microphylla plantations.

\section{Conclusions}

The establishment of A. ordosica, C. korshinskii and C. intermedia plantations on sand dunes has greatly ameliorated soil quality in the Gonghe Basin (northeastern Tibetan Plateau). Relative to the moving sand dunes, shrub plantation has increased silt and clay contents, water holding 
capacity, SOM, TN, TP and TK contents. The TN contents of C. intermedia and C. korshinskii were increased dramatically because both $C$. intermedia and C. korshinskii are nitrogen-fixing leguminous shrubs that can fix free nitrogen from the air. The SQI indicated that in the Gonghe Basin, C. intermedia is the best choice for soil amelioration. In all the three plantation types, soil amelioration mainly occurred in shallow depths.

\section{Acknowledgements}

This research was supported by the Forestry Public Benefit Scientific Research Special Project of China (201504420), and the National Science \& Technology Pillar Program during the $12^{\text {th }}$ Five-year Plan Period (2012BAD16B0102).

\section{References}

Andrews S S, Karlen D L, Mitchell J P. 2002. A comparison of soil quality indexing methods for vegetable production systems in northern California. Agriculture, Ecosystems \& Environment, 90(1): 25-45.

Bastida F, Moreno J L, Hernández T, et al. 2006. Microbiological degradation index of soils in a semiarid climate. Soil Biology and Biochemistry, 38(12): 3463-3473.

Bochet E, Rubio J L, Poesen J. 1999. Modified topsoil islands within patchy Mediterranean vegetation in SE Spain. Catena, 38(1): 23-44.

Cao C Y, Jiang S Y, Ying Z, et al. 2011. Spatial variability of soil nutrients and microbiological properties after the establishment of leguminous shrub Caragana microphylla Lam. plantation on sand dune in the Horqin Sandy Land of Northeast China. Ecological Engineering, 37(10): 1467-1475.

Dong G R, Gao S Y, Jin J. 1993. Land Desertification and its Remedial Measures in the Gonghe Basin, Qinghai Province. Beijing: Science Press, 15-25. (in Chinese)

Dong X W, Zhang X K, Bao X L, et al. 2009. Spatial distribution of soil nutrients after the establishment of sand-fixing shrubs on sand dune. Plant Soil and Environment, 55(7): 288-294.

Fang X W, Wang X Z, Li H, et al. 2006. Responses of Caragana korshinskii to different aboveground shoot removal: combining defence and tolerance strategies. Annals of Botany, 98(1): 203-211.

Gao G L, Ding G D, Zhao Y Y, et al. 2014. Fractal approach to estimating changes in soil properties following the establishment of Caragana korshinskii shelterbelts in Ningxia, NW China. Ecological Indicators, 43: 236-243.

Gao L F, Hu Z A, Wang H X. 2002. Genetic diversity of rhizobia isolated from Caragana intermedia in Maowusu sandland, north of China. Letters in Applied Microbiology, 35(4): 347-352.

Gao R H, Shi J, Huang R F, et al. 2015. Effects of pine wilt disease invasion on soil properties and Masson pine forest communities in the Three Gorges reservoir region, China. Ecology and Evolution, 5(8): 1702-1716.

Institute of Soil Sciences, Chinese Academy of Sciences (ISSCAS). 1978. Physical and Chemical Analysis Methods of Soils. Shanghai: Shanghai Science Technology Press, 62-136. (in Chinese)

Jia G M, Liu B R, Wang G, et al. 2010. The microbial biomass and activity in soil with shrub (Caragana korshinskii K.) plantation in the semi-arid loess plateau in China. European Journal of Soil Biology, 46(1): 6-10.

Jia Z Q, Zhu Y J, Liu L Y. 2012. Different water use strategies of juvenile and adult Caragana intermedia plantations in the Gonghe Basin, Tibet Plateau. PLoS ONE, 7(9): e45902.

Jiang D M, Cao C Y, Zhang Y, et al. 2014. Plantations of native shrub species restore soil microbial diversity in the Horqin Sandy Land, northeastern China. Journal of Arid Land, 6(4): 445-453.

Li Q X, Wang Y S, Zhu Y J, et al. 2014. Effects of soil improvement of Caragana intermedia plantations in alpine sandy land on Tibet Plateau. Acta Ecologica Sinica, 34(2): 123-128. (in Chinese)

Li S G, Harazono Y, Zhao H L, et al. 2002. Micrometeorological changes following establishment of artificially established Artemisia vegetation on desertified sandy land in the Horqin sandy land, China and their implication on regional environmental change. Journal of Arid Environments, 52(1): 101-119.

Li X R, Zhang J G, Wang X P, et al. 2000. Study on soil microbiotic crust and its influences on sand-fixing vegetation in arid desert region. Acta Botanica Sinica, 42(9): 965-970. (in Chinese)

Li Y Q, Awada T, Zhou X H, et al. 2012. Mongolian pine plantations enhance soil physic-chemical properties and carbon and nitrogen capacities in semi-arid degraded sandy land in China. Applied Soil Ecology, 56: 1-9.

Liu L Y, Jia Z Q, Zhu Y J, et al. 2012. Water use strategy of different stand ages of Caragana intermedia in alpine sandland. 
Journal of Arid Land Resources and Environment, 26(5): 119-125. (in Chinese)

Lu Q, Wang X Q, Wu B, et al. 2009. Can mobile sandy land be vegetated in the cold and dry Tibetan Plateau in China?. Frontiers of Biology in China, 4(1): 62-68.

Luo Y Q, Zhao X Y, Andrén O, et al. 2014. Artificial root exudates and soil organic carbon mineralization in a degraded sandy grassland in northern China. Journal of Arid Land, 6(4): 423-431.

Masto R E, Chhonkar P K, Singh D, et al. 2008. Alternative soil quality indices for evaluating the effect of intensive cropping, fertilisation and manuring for 31 years in the semi-arid soils of India. Environmental Monitoring and Assessment, 136(1-3): 419-435.

Sinha S, Masto R E, Ram L C, et al. 2009. Rhizosphere soil microbial index of tree species in a coal mining ecosystem. Soil Biology and Biochemistry, 41(9): 1824-1832.

Su Y Z, Zhang T K, Li Y L, et al. 2005. Changes in soil properties after establishment of Artemisia halodendron and Caragana microphylla on shifting sand dunes in semiarid Horqin Sandy Land, Northern China. Environmental Management, 36(2): $272-281$.

Wang X P, Li X R, Xiao H L, et al. 2006. Evolutionary characteristics of the artificially revegetated shrub ecosystem in the Tengger Desert, northern China. Ecological Research, 21(3): 415-424.

Wezel A, Rajot J L, Herbrig C. 2000. Influence of shrubs on soil characteristics and their function in Sahelian agro-ecosystems in semi-arid Niger. Journal of Arid Environments, 44(4): 383-398.

Yang H, Lu Q, Wu B, et al. 2006. Vegetation diversity and its application in sandy desert revegetation on Tibetan Plateau. Journal of Arid Environments, 65(4): 619-631.

Yang Z P, Zhang Q, Wang Y L, et al. 2011. Spatial and temporal variability of soil properties under Caragana microphylla shrubs in the northwestern Shanxi Loess Plateau, China. Journal of Arid Environments, 75(6): 538-544.

Yu Y, Jia Z Q. 2014. Changes in soil organic carbon and nitrogen capacities of Salix cheilophila Schneid along a revegetation chronosequence in semi-arid degraded sandy land of the Gonghe Basin, Tibet Plateau. Solid Earth, 5(2): 1045-1054.

Zhang C, Xue S, Liu G B, et al. 2011. A comparison of soil qualities of different revegetation types in the Loess Plateau, China. Plant and Soil, 347(1-2): 163-178.

Zhang D S, Gao S Y, Shi M Y, et al. 2009. Sandy Desertification and it's Control in the Qinghai Plateau. Beijing: Science Press, 6-40. (in Chinese)

Zhang W R, Xu B T. 1986. The Method of Long-term Research on Forest Soil. Beijing: Chinese Forestry Press, 30-36. (in Chinese)

Zhang Y, Cao C Y, Han X S, et al. 2013. Soil nutrient and microbiological property recoveries via native shrub and semi-shrub plantations on moving sand dunes in Northeast China. Ecological Engineering, 53: 1-5.

Zuo X A, Zhao X Y, Zhao H L, et al. 2009. Spatial heterogeneity of soil properties and vegetation-soil relationships following vegetation restoration of mobile dunes in Horqin Sandy Land, Northern China. Plant and Soil, 318(1-2): $153-167$. 